\title{
GREAT WESTERN BUILDS OELWEIN SHOPS
}

\author{
Construction of the C. G. W. Railway Machine \\ SHOPS IN 1894-991
}

\section{By James Thomas Craig}

On behalf of the business and professional men of Oelwein, R. N. Baylies and John Jamison signed a contract with the Chicago Great Western Railway Company on April 17, 1894. They agreed to furnish the site and $\$ 200,000$ toward the cost of erecting new buildings, provided the railway company bring its principal machine and repair shops to Oelwein. They were extremely anxious to secure such a large industrial enterprise for the growth and prosperity of their town. Their efforts, and later those of A. B. Stickney, president of the C. G. W., in financing the construction of the main shops of the "Maple Leaf Route" during the years 1894-1899 form this history. ${ }^{2}$

1This is the second article on the history of the Oelwein shops of the Chicago Great Western Railway Company by Mr. Craig. The first article, "Oelwein Secures the C. G. W. Shops, 1894," appeared in THE ANNALS OF IowA, Third Series, Vol. XXIV, No. 3, Jan., 1943, Part 1, pp. 210-235.

At the time he did the research for this article, in 1942, Mr. Craig taught history in the senior high school in Oelwein. He is now employed as an instructor in history in the senior high school, Muskegon, Michigan. Mr. Craig received his master's degree in history in 1941 from Washington University, St. Louis, Missouri.

"Baylies was a rather widely-known judge formerly of Des Moines; then of Chicago. The Oelwein Register, Apr. 7, 19, 1894.

Jamison was connected with the State Bank of Oelwein. Belt, B. L., statement to author, July 28, 1942 ; C. G. W. Ry. Co., Corp. Rec., Vol. 1, pp. 240-242.

A. B. Stickney, president of the C. G. W., explained the $\$ 200,000$ as follows:

"The change [in location of the shops] was hedged about with difficulties from the fact that the company [C. G. W.] has already invested in shop plant at St. Paul more than $\$ 300,000$, which would be of little value for anything else so far as we can now foresee. Therefore, to change the location the Company estimated that it would involve a loss of about $\$ 200,000$. The projectors of the Oelwein Land Company [E. F. House and R. N. Baylies] conceived the idea of making good this loss by turning over to the company [C. G. W.] a portion of the enhanced value of its lands...

The promoters of the Oelwein Land Company expected the land company would be reimbursed for its outlay by an increase in value of its lands. The enhanced value was to result from the increased population following the location of the shops in Oelwein."

On Apr. 7,1894 , it was reported that the shop buildings were to cost $\$ 375,000$, but on June 7, 1894, Stickney said: "The shops, yards, and appurtenances which will have to be provided at the outset will cost approximately $\$ 250,000$ to $\$ 300,000$." The Oelwein Register, Apr. 7, May 3, June 7, 1894; The St. Paul Pioneer Press, June 3,1894: Stickney, A. B.. Third Annual Report to the Stoekholders of the C. G. W. Railway Company, June 30,1895 , p. 9.

Predecessor companies of the C. G. W. had been known, successively, as the Maple Leaf Route, the Diagonal, and the Chicago, St. Paul \& Kansas City Railroad. In 1894 the C. G. W. was known as the Maple Leaf Route. After its reorganization in 1909 it was termed the Corn Belt Route. The Oelwein Register, Apr. 26, Aug. 20, 1894 . 


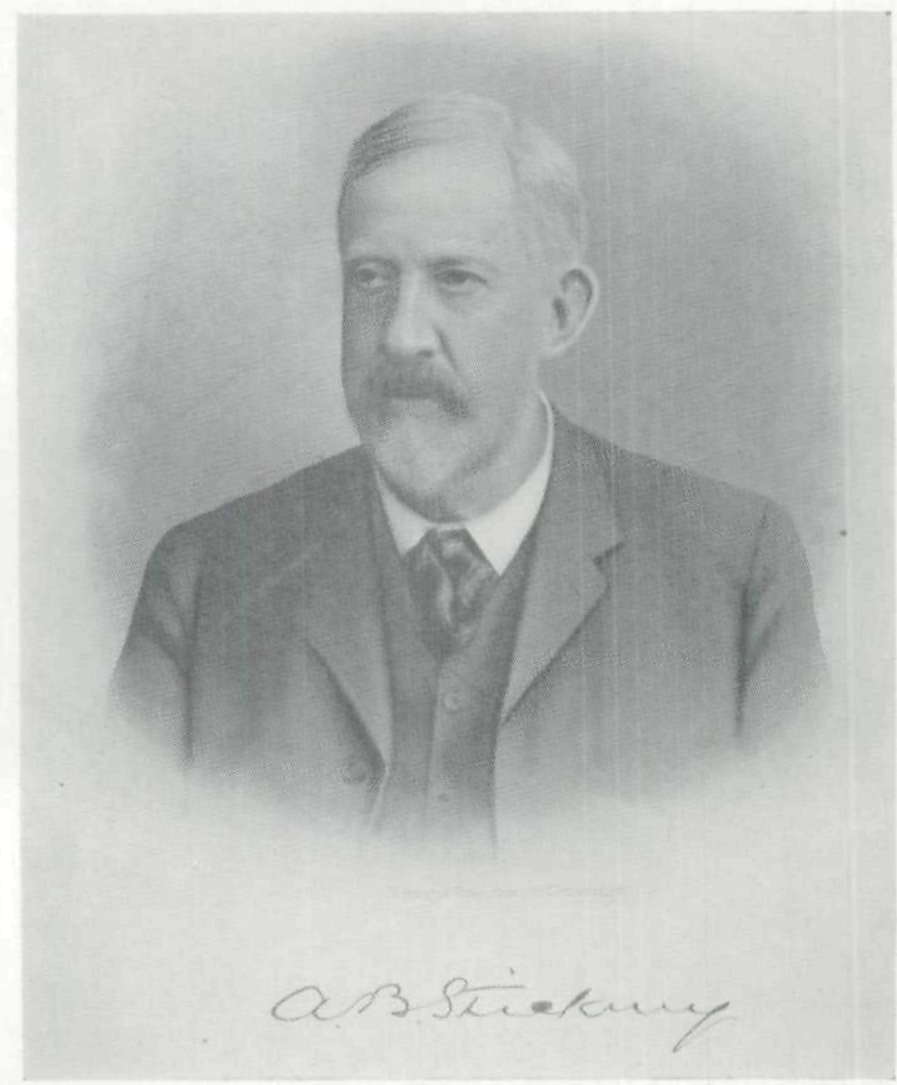

A. B. STICKNEY

President Chicago Great Western Railway Co. Financed the Construction of Oelwein Machine Shops and Division Facilities 
When first propositioned the business and professional men of Oelwein had been very enthusiastic over the prospect of securing large railway shops. In less than five days they had obtained options on all land surrounding the town. On April 4 they had organized the Oelwein Land Company with E. F. House as general manager. According to the terms of the contract the land company was to sell the optioned land and apply the proceeds as follows: ${ }^{3}$

1st. In payment for said lands or so much thereof as it may deem best to purchase at the price agreed upon in the options, together with the expenses of platting and selling the same.

2nd. In payment of $\$ 200,000$ for the construction of car shops, yards, and appurtenances, according to the plans and under the supervision of the railway company.

3rd. Any balance shall belong exclusively to the land company and the land company further agrees that when it has expended said $\$ 200,000$ as aforesaid, it will convey said shops and the land appropriated to shop purposes to the railway company.

House started immediately the movement to "boom" the optioned land. He was instrumental in organizing a board of trade the same week the contract was signed. Its expressed object was to advertise Oelwein to "capitalists, investors, and home-seekers everywhere." Also, the same week he arranged with D. McDonald, Stewart \& Company, realtors of Chicago, to come to Oelwein and assist the land company in selling the land. By April 19 representatives of this firm had arrived and set up an office in the Wachtel building at the intersection of Frederick avenue and Charles street. Offices of the land company were located in the Jamison building on South Frederick. $^{4}$

\footnotetext{
3Thursday, Mar. 9, to Monday, Apr. 2, 1894. The Oelwein Register, Apr. 7, 1894. Options were obtained on two thousand acres. The Oelwein Register, Apr. 7, 19, 1894.

House was a land promoter said to have come from New York, N. Y. He and Baylies had been engaged by Stickney to proposition the businessmen of Oelwein. The Oelwein Register, Apr. 7, 1894.

In addition to House and Baylies, the directors of the Oelwein Land Company included Arnold Kalman, Ansel Oppenheim, and John Jamison. Kalman and Oppenheim were directors of the C. G. W.; Kalman being a vice-president. The Oelwein Register, Apr. 7, 12, 26, 1894; Note to Eliza M. Hanson, signed by thirty-two Oelwein businessmen, Apr. 17, 1894; Belt, op. cit.; C. G. W. Ry. Co., Corp. Rec., Vol. 1, pp. 240-242.

*The Oelwein Register, Apr. 12, 19, July 12, Aug. 29, 1894.
} 
Word that Oelwein had secured the C. G. W. shops spread to other northeastern Iowa towns along the line of the C. G. W. In particular, were the businessmen of Elma, Sumner, and Dubuque interested. They had heard that the C. G. W. officials had planned to consider each of their towns had Oelwein not been interested. The board of trade members in Dubuque were especially interested, and sent J. P. Bushnell, their secretary, to Oelwein to investigate. Bushnell was shown a copy of the contract and upon his return to Dubuque wrote in part: ${ }^{5}$

Hard times are not supposed to be productive of booms, but that does not apply to Oelwein, the enterprising town seventy miles out from Dubuque. It is probably the only place in the country at present with a good well-developed case of boom on hand. The reason .... the announcement by the C. G. W. that the shops of that railroad company will be located there... The people are naturally quite excited over the streak of luck, and expect to have a city of 15,000 inhabitants within three or four years ... Oelwein is a good town .... and there is no reason why it should not boom and go ahead. To say that the boom is well founded, it is enough to say that President A. B. Stickney is back of it.

During May considerable of the optioned land was marked off in lots by B. F. Little, surveyor for the Oelwein Land Company. He laid out lots first in the northeast part of town in the Oelwein Land Company's addition. This addition lay north of Fairview Heights and Wing's first and second additions. Next, lots were laid out in the Armstrong addition in the southwest part of town. ${ }^{6}$

\section{LAND SALE OF LOTS Held}

By May 28 House was ready to hold a land auction. On that date a "Great Land Sale" was held in a tent on the south side of Charles street just west of Sixth avenue S. W. A contemporary merchant states that the C. G. W. furnished transportation free to all persons interested in attending the sale. He recalls that there must have been

\footnotetext{
5The Oelwein Register, Apr. 7, 1894; The Dubuque Herald, reprinted in The Oelwein Register, Apr. 26, 1894.

The Oelwein Register, Apr. 19, 1894; Belt, op. cit.; Smith, Thomas, and Richard H., statements to the author, Aug. 1, 1942.
} 
over ten thousand people in Oelwein that day. The Hon. Gilbert N. Haugen, U. S. Representative from the Fourth Congressional District of Iowa, attended and purchased several lots. A newspaper reporter from St. Paul was on hand and at noon telegraphed the following account to his editor $:^{7}$

Oelwein is rejoicing over the climax of its boom! May 28-This is the greatest day in the history of Oelwein, or any other northern Iowa town for that matter, and the boom is now on. Before 9:00 o'clock the streets were congested with people from the town and the country before a train arrived. Business houses and many residences are gaily trimmed with flags, bunting and streamers, presenting a beautiful appearance. The first special train arrived at 10:30 A. M. from Dyersville and points between. It consisted of nine coaches filled to the steps with probably a thousand people. They were escorted to the big tent of the Oelwein Land Company by fifty members of local police and firemen. By 12:30 P. M. specials from Des Moines, Dubuque and Marshalltown will bring over thousands. The Iowa state band will be with the Des Moines delegation. The day is clear and beautiful, and everything indicates that the great real estate sale will be a success.

At the sale lots were auctioned. Most of the lots were paid for in cash; others with negotiable paper. Terms were arranged for those purchasers who desired to buy lots on time. A contemporary states that many of the lots sold on time reverted back to the land company for lack of payment. Other contemporaries declare: "They really didn't sell much land that day. It was half a fake deal. The fellows on the ground floor knew what was going on, but otherwise .... it [the sale] was a fizzle!"s

Though hardly a fizzle, the sale was no success. House declined to attempt other sales, preferring instead to offer large tracts of land to manufacturers and industrialists. He arranged with the board of trade to invite out-of-town manufacturers and capitalists to come to Oelwein and investigate the opportunities offered. Oelwein businessmen made numerous excursions to towns along the line of the C. G. W. during the summer and fall of

\footnotetext{
7The St. Paul Dispatch, May 28, 1894 ; Smith, Thomas, and Richard H., op. cit.; Oelberg. James, statement to the author, Aug. 1, 1942; Shields, J. Kirk, statement to the author, July 31,1942 . The Smith brothers were grocers; Oelberg, a shoestore proprietor.

'Smith, Richard H., and Thomas, op. cit.; Oelberg, op. cit.; Shields, op. cit.
} 
1894, but with little success. Only one manufacturing concern was brought to Oelwein. That was the James Sorenson Company, of Lyons, Iowa, makers of moldings, window frames, and screens. No record of any large investment of capital in Oelwein real estate or industry by out-of-town capitalists has been found. ${ }^{9}$

Meanwhile, House did not neglect the sale of lots. Homesites were sold to operating officials of the C. G. W., then being transferred to Oelwein in ever-increasing numbers. Especially did House endeavor to sell entire subdivisions to realtors. In this way he hoped sufficient houses would be ready for occupancy by the time the shops were completed and put into operation. In speaking before the people of Oelwein June 2, Stickney said: "About five hundred dwelling houses should be ready for occupancy as soon as the shops are completed, to be increased to one thousand dwelling houses within a very few years."10

To attract the attention of building contractors House arranged with William Bentley, in July, 1894, to clear and grade the reported site of the shops and other manufacturing establishments. Beginning near West Charles street on the line of the C. G. W., the site extended north three-quarters of a mile. To the east of the track a space 480 feet in width was reserved for the shops and factories; to the west a space of 200 feet in width was to be used for switch-yards. On August 30, when in Oelwein to learn what progress had been made in the sale of land, Stickney inspected Bentley's grading. That things were not going well with the land company may be noted by his reply when asked the time the grading was to be finished: "If completed within a year, Oelwein will have no reason to complain." 11

\footnotetext{
9Smith, Thomas, op. cit.; The St. Paul Dispatch, June 5, 1894; The Oelwein Register, July 12, 1894.

${ }^{10}$ In January, 1894, Oelwein had been made the operating center of the C. G. W. The Oelwein Register, Jan. 11, June 7, 1894.

11Oelberg, op. cit.; Smith, Thomas, op. cit.; The Oelwein Register, Apr. 19, Sept. 6, 1894.
} 


\section{OBJECTIVE WAS IN JEOPARDY}

During the fall of 1894, and the winter months following, very little land was sold by the Oelwein Land Company. By the terms of the contract the C. G. W. did not have to transfer its shops to Oelwein if the land and $\$ 200,000$ were not available by April 1, 1895. In March it was common knowledge that the money had not been raised. House began to act. First, he drew up and distributed among twenty of the business and professional men notes, each for one thousand dollars. In return for their cash they were to receive lots in the Oelwein Land Company's addition. They were asked to secure as many signatures to each note as possible. The money thus raised helped, but House was still far short of the $\$ 200$,000 . Next, he endeavored to raise money by selling stock in the Oelwein Land Company. Shares of stock were offered for sale at one hundred dollars per share. In appealing to the businessmen a second time House pointed out that unless the money or "good securities" were available by April 1st, Oelwein might not get the C. G. W. shops after all! Just how much money he raised by the sale of the stock is not known. But what is known, however, is that he failed to raise the $\$ 200,000$. As a last resort he asked for cash donations from the business men. In this he met with even less success than in his other schemes. Little money was obtained and considerable friction developed among the merchants as to just how much each was to donate. ${ }^{12}$

As the year of option ended, A. E. Woodruff, of the Oelwein Register, endeavored to be encouraging in saying : ${ }^{13}$

Considering the financial difficulties and other disadvantages under which the company has had to labor during the past year the work accomplished has been very gratifying... There is no doubt but what the company will accomplish what it set out to doto secure the erection of the C. G. W. machine shops here. We have faith in the enterprise, not only because such men, and others, are

12C. G. W. Ry. Co., Corp. Rec., Vol, 1, pp. 240-242; The Oelwein Register, Apr. 26, 1894; Smith, Thomas, and Richard H., op. cit.; Oelberg, op. cit.; Belt, op. cit.

18 The Oelwein Register, May 9, 1895. 
behind it, but because we have faith in Mr. Stickney and his work, and he has never waivered since the project was started.

The occasion for Woodruff's remarks had been the annual meeting of the stockholders of the Oelwein Land Company two days previous. Stickney and Ansel Oppenheim, the latter a vice-president of the C. G. W., had met with House, Jamison, John Irvine, and Bentley. An election of officers had been held. Irvine was elected president, replacing Baylies; House was re-elected vice-president and general manager; and H. J. Fels was chosen secretary-treasurer in place of Jamison. While the books of the land company were being audited Woodruff prophesied that "Within a few weeks matters between the Oelwein Land Company and the C. G. W. Railway and the proposed shops will take such form that there will no longer be any doubt in the minds of our citizens in regard to the outcome of an enterprise which means so much for our town."14

After hearing the auditor's report on the financial condition of the Oelwein Land Company, the C. G. W. directors agreed that the project should not be dropped. The shops were to be built in Oelwein after all! At a special meeting in St. Paul May 23 the directors resolved to invest in lots of the land company all profit made in Oelwein for a year beginning June 1st! House was told that he might use the money made in selling the lots in grading the new site or in the erection of the buildings. He was advanced $\$ 6,500$ by the directors. ${ }^{15}$

Evidently Stickney had not approved the location of the shops in the northwest part of town for in June a new location was announced. Beginning at the roundhouse, at the point where the branch line extending to Kansas City left the main line, the new site lay north along the main line to Charles street and west to Sixth Avenue S. W. This section, situated directly west of the business district, was then heavily wooded and was known as "Oelwein's Grove." The earlier graded area to

${ }^{14 T h e}$ Oelwein Register, May 9, 16, 1895.

${ }^{15}$ C. G. W. Ry. Co., Corp. Rec., Vol. 1, p. 421. 
the north of Charles street was to be used as a switching yard. ${ }^{16}$

\section{BEGINNING OF WORK ANNOUNCED}

It was not long after the C. G. W. directors decided to go ahead with the shops that Woodruff announced that work had begun. ${ }^{17}$

All preliminaries have been completed and active operation will be the order of the day from this time on. Largest railroad shops in the state!

The new officers of the Oelwein Land Company have taken hold of their part of the work in securing the C. G. W. machine shops in Oelwein in a manner which shall secure success. That these gentlemen have the ability to push forward the work is fully demonstrated by the events of the past few weeks, and especially the past few days.

On Monday morning a force of about thirty men was set to work clearing off the location decided upon for the shops, and it has been increased until now four stump pullers and fully fifty men are finding employment in this work ...

The engineers of the railway company began work today on the survey for straightening the channel of the creek, which of itself is no small undertaking ... It is now thought that the contract for laying the foundations will be let next week. Arrangements are already being made for the stone and other material for the foundations.

As Woodruff indicated, the contract for the mason work on the foundations was let the last week of June. From a group of eight bidders, John Eller \& Sons, of Manchester, Iowa, was chosen. On July 2 the contract for furnishing the stone was let to T. H. Houston of Minneapolis. ${ }^{18}$

By July 4 two of the trenches for the foundations of the main building had been dug and the work of straightening the creek nearly completed. A contemporary laborer states: ${ }^{19}$

I worked on the scraping and digging of the trenches for the foundations. I also worked on the straightening out of the branch

\footnotetext{
${ }^{10}$ Smith, Thomas, and Richard H., op. cit.; Oelberg, op. cit.; Belt, op. cit.; The Oelwein Register, May 16, June 20, July 28, 1895.

17'The Oelwein Register, June 20, 1895.

1sThe Oelwein Register, July 4, 1895.

${ }^{10}$ Smith, Thomas, op. eit.
} 
of Otter creek, which meandered all over the shop site. I worked a team on a wheeler-scraper moving the creek. We dug down sixteen feet and filled in other places so as to get it to drain at the lower end.

According to the Oelwein Register the creek channel was " 26 feet at the top and 12 feet in width at the bottom, and 1700 feet in length, with a fall of 16 feet in the 1700." 20

On July 28 it was reported :21

The past week has been a busy one on the grounds where the C. G. W. shops are being built ... A About twenty car-loads of stone for the foundations have been received and unloaded, a sidetrack having been put in for the accommodation of the workmen .... Another sidetrack is being put in, the trenches for the next largest buildings are being dug, and by the first of next week, as soon as the large stone-lifting derricks ean be put up, lime and other material be got on the ground, work will be rushed.

Mr. Reed, the supervising architect, says that it is hoped to get the foundations in by November, and that if they are completed by that time, work will be carried on all winter on the superstructure, the steel framework, and roofing being put in place to be followed by the brick work in the early spring and summer of next year.

In his enthusiasm Woodruff made two mis-statements during August. On the 15th he wrote: "The shops are to be completed by one year from November 1, 1895." True, House had said the previous month, in advertising stock and land for sale, that "The shops will be completed and occupied within two years." Nevertheless, Woodruff undoubtedly knew that House still lacked the building fund and that the expense of laying the foundations was rapidly depleting what cash House did have! After the C. G. W. directors had decided to go ahead with the shops in Oelwein, House was all the more determined to carry construction as far as possible. On August 22 Woodruff erred again. In one sentence he said "One corner of the foundation of the main building has reached its height." A sentence or two later he declared: "The foundations are now laid!" In reality the foundations were not all laid. And, he wrote: "Wednesday 21 bids will be opened

20The Oelwein Register, July 4, 1895.

${ }^{21}$ The Oelwein Register, July 28, 1895. 
for work on structures which will amount to $\$ 150,000-$ structural work alone. Outside of this are the finishing touches." Not until March, 1898, was the contract let for construction of the shop buildings proper $!^{22}$

\section{Building Plans made available}

On August 29 the Oelwein Register carried on its front page a rough sketch of the "New C. G. W. Shops." Tracy Lyon, general master mechanic of the C. G. W., had earlier planned the general layout of the shops. Woodruff hoped that his printing of this sketch would stimulate the sale of Oelwein real estate and encourage out-of-town industrialists to locate in Oelwein. ${ }^{23}$

Reed had predicted well in saying that the foundations might be completed by November. Early that month it was reported: "The great railroad shops in Oelwein are materializing in fine shape. The stone work for the walls are nearing completion and preparation is being made for the steel superstructure." But from here on it was not like the architect had expected. The winter months did not see the steel framework arise! Nor was any brick-laying done on the shop buildings during the spring of '96. The Oelwein Land Company simply did not have the funds with which to erect the shops! On May 17 the stockholders of the land company held their annual meeting. Jamison, Irvine, and Bentley, of Oelwein, and Oppenheim and Robert C. Wight, the latter secretary of the C. G. W., were elected directors. At the directors' meeting that evening all the incumbent officers were reelected. Stickney announced that the C. G. W. planned to complete the construction of the shops, but just when he did not say. Before going ahead with the shops, he did indicate, the C. G. W. intended to cut down the grades approaching the town and to level the switch-yard. This work was to be done during the summer of $1896 .{ }^{24}$

29The Oelwein Register, Aug. 15, 22, 1895; Mar. 30, 1898.

2.The Oeiwein Register, Aug. 29, 1895; The Railway Age, Mar. 2, 1900, pp. 174; Engineering News \& American Railway Journal, Mar. 22, 1900, p. 185: Railway Master Mechanic, Mar., 1900, pp. 110-129; The Railway \& Engineering Review, Apr. 16, 1898, pp. 200-201.

${ }^{24}$ The New Hampton Courier, reprinted in The Oelwein Register, Nov, 7, 1895 ; The Oelwein Register, June 18, 25, 1896. 
Not until October 8th was it reported that work on the foundations had been resumed. On that date Woodruff stated that: ${ }^{25}$

Workmen have been engaged the past week or ten days on the C. G. W. machine shops foundation and the work is to be prosecuted from now on until it freezes up. Much of the other construction work that has occupied attention all summer is out of the way, so that more attention can be paid to this important enterprise the remainder of the season.

Despite the fact that work had been resumed there were many people who seriously doubted that the shops were to be finished. Woodruff investigated and quoted John Eller \& Sons as saying :26

There is not the least doubt now that the shops are to be finished. The force is to be increased at once and the work on which we are now engaged would not be done unless the company was intending to complete the work. We expect to push the work as long as the weather will permit.

The Ellers stated that the coping on the foundations had just been completed. On October 19th they were reported as putting in place the finishing stones. No news of further construction was reported in the Oelwein Register until May, $1898 .{ }^{2 \pi}$

At the annual meeting of the stockholders of the Oelwein Land Company, May 2, 1897, no mention was made of completing the shop buildings. Wight, representing President Stickney, announced that the C. G. W. intended finishing the switchyard during the coming summer. Nevertheless, Woodruff assumed that, since the C. G. W. directors had already invested over $\$ 15,000$ in Oelwein real estate, in addition to their expenditures on the foundations, they would surely resume construction of the shops during $1897 .^{28}$

At the meeting of the directors of the Oelwein Land Company, following the annual stockholders' meeting, Irvine was elected general manager, replacing House.

${ }^{25}$ The Oelwein Register, Oct. 8, 1896.

${ }^{20}$ The Oelwein Register, Oct. 22, 1896.

27The Oelwein Register, Oct. 19, 1896 ; May 4, 11, 1898.

${ }^{25}$ The Oelwein Register, May 4, 1897. 
This marked the end of the activities of the two land promoters sent to Oelwein by Stickney in the spring of 1894. Irvine had replaced Baylies as president of the land company in $1895 .{ }^{29}$

\section{WORK RESUMED AND FINANCED}

The C. G. W. did, as Woodruff figured, resume work on the shops, but not until the following spring. To understand just how the shops were financed by the C. G. W. it is necessary to know Stickney's financial methods. On January 5, 1892, he had reorganized the bankrupt Chicago, St. Paul \& Kansas City Railway Company into the Chicago Great Western Railway Company. His plan of reorganization was unique and without parallel in the long history of railroad reorganizations in the United States. The reorganization was made entirely on a stock basis, the C. G. W. not issuing a bond of any kind. Stickney effected the reorganization without any foreclosure or court proceedings; in fact, without even a receiver! "The reorganization was not made easy," said he, "by reason of the first mortgage bonds being held by a syndicate, or in the hands of a few, for they were held by nearly 3,000 investors scattered over England and the continent of Europe, with a few in the United States." In addition, the C. St. P. \& K. C. Railway directors had borrowed approximately $\$ 3,000,000$ at 5\% interest in 1889 . In their efforts to meet the interest payments they had allowed the property to deteriorate in the years following. Consequently, when the C. G. W. was organized, in 1892, its directors faced the problem of putting the roadbed back in shape and purchasing new motive power and rolling stock as well as the problem of paying off the three million dollar debt $!^{30}$

29rThe Oelwein Register, May 9, 16, 1895 ; May 4, 1897.

oBogart, Ernest L., "Alpheus Beede Stickney," The Dictionary of American Biography, Vol. XVIII, pp. 15-16:

"Stickney, A. B.-born in Wilton, Me., June 27, 1840, the son of Daniel and Ursula Maria (Beede) Stickney... Educated in the common schools and academies of Maine and New Fampshire until he was eighteen. He then began the study of law in the office of Josiah Crosby in Dexter, Me. His preparation was somewhat delayed by school-teaching which he was obliged to undertake in order to earn money, but in 1862 he was admitted to the bar, and moved to Minnesota, where he practiced law until 1869 . Railroad building was just beginning in Minnesota and neighboring states, and in 1869 Stickney moved to St. Paul, gave up 
It was due entirely to his plan of reorganization that Stickney was able to obtain financial aid at a time when money was difficult to get. It will be recalled that in the year 1893 the United States experienced one of the worst financial panics in its history. The Panic of 1893 was caused primarily by the over-expansion of railroads which, as a result of the importation of British capital, had created a boom that collapsed when the railways failed to meet their financial obligations. One fourth of the railroads in the country went bankrupt, but not the C. G. W.! To keep English capital coming in Stickney acquisced to English practice in financing railroads! $\mathrm{He}$ gave control of the C. G. W. to a group of London financiers, making it the first railway in the United States to be controlled from abroad! Stickney was the first, and only, president of an American railroad to deliberately abandon the method of raising money by mortgage bonds. Instead, he accepted debenture stock. He defined this form of stock as follows: ${ }^{31}$

Debenture stock is a favorite form of security in England, but has never been introduced in the United States. It partakes of the nature of both stocks and bonds ... It has a lien upon the income of the railway for its interest.

Contemporary editors of The Railway Age went on to say $:^{32}$

his practice, and became connected with railroad enterprises. His first great undertaking, in 1871, was the St. Paul, Stillwater \& Taylor's Falls Railroad-later a part of the Chicago, Minneapolis \& Omaha system-which he served for several years as vice-president, general manager, and chief counsel. In 1879 he became superintendent of construction of the St. Paul, Minneapolis \& Manitoba Railway, which subsequently became part of the Great Northern, and the following year was general superintendent of about 500 miles of the Canadian Pacific Railway. In 1881 he organized and built the first section of the Wisconsin, Minnesota \& Pacifie Railroad, and in 1881-1882 he was vice-president of the Minneapolis \& St. Louis Railway. In 1883 he organized and began construction of the Minnesota \& Northwestern Railroad, serving as president until its union with the Chicago, St. Paul \& Kansas City in 1887, and then as president of the consolidated road. This office he held until 1892, when he was elected chairman of the board of directors. In that capacity he reorganized the road as the Chicago Great Western Railway, of which he was elected president in $1894 . "$

Also from The Biographical Directory of the Railway Officials of America, Vol. 3 (1898 edition), by T. A. Busbey, p. 354. Published by The Railway Age and The Northwestern Railroader.

The Oelwein Register, Feb. 23, 1898 ; C. G. W. Ry. Co., Corp. Rec., Vol. I, pp. 1-12; Stickney, A. B., A Short History of the Finances of the C. G. W. Ry. Co., 1899 , pp. 4-8

siTilinghast, W. H., Ploetz' Epitome of History, p. 663; Langer, An Encyclopaedia of World History, p. 794; Hamm, W. H., The American People, pp. 689690 ; Herapath's Railway Journal, London, Jan. 26, 1900, p. 81.

C. G. W. Ry. Co., Corp. Rec., Vol. 1, pp. 1-12; Dictionary of American Biography, op. cit.; Stiekney, A. B., A Short History, op. cit., o. 5

22 Editorial, "C. G. W. Finances," The Railway Age, Mar. 3, 1899, p. 146. Also, The Railway Age, Aug. 13, Oct. 22, 1897 ; Stickney, A Short History, op, cit., p. 5. 
As a stock it participates in the management in all respects the same as other stocks ... . Like a bond, debenture stock bears a fixed rate of interest which must be paid semi-annually . . . It is a perpetual security, not terminable like a bond by lapse of time, and the rate of interest cannot be cut down by default, foreclosure and reorganization.

In his relying solely on a stock basis Stickney was criticized sharply by publishers of railway journals in both the United States and England. American publishers firmly upheld the "time-honored" plan of bonding, while English journalists asserted that the basis on which Stickney had made his arrangement with the London capitalists was too narrow and that the debenture stockholders were too exclusively English. They felt that there was no general market, in England or in the United States, in which the debenture stock could be readily sold. Nevertheless, Stickney was positive that the debenture stock plan was best. He actually thought it could not fail! He convinced the C. G. W. directors that there was far less risk, from the financial standpoint, by having the C. G. W. financed with debenture stock than being closely tied down with heavy mortgages! Consequently, in 1895, and in the years following, English capital was obtained by the C. G. W. for use in reducing grades, replacing temporary culverts and bridges with permanent structures, ballasting the roadbed, purchasing new motive power and rolling stock, building branch lines, and, as we shall soon see, constructing the Oelwein shops $!^{33}$

\section{RAIL EARNINGS REDUCED IN NINETIES}

It has been pointed out that the work on the foundations of the shop buildings had stopped the last of October, 1896. No construction of the buildings above the foundations had been attempted. Stickney knew that eventually the shops would have to be completed. Reduc-

${ }^{38}$ C. G. W. Ry. Co., Corp. Rec., Vol. 1, pp. 7-8; The Railway Age, Aug. 13, Oct. 22, 1897; Mar. 3, 1899, pp. 146-147; Herapath's Railway Journal, London, Jan. 26, 1900, D. 81; Stickney, A. B., Fourth Annual Report to the Board of Directors of the C. G. W. Ry. Co., June 30, 1896, p. 3; Fifth Annual Report . . June 30, 1897 , p. 3; The Oelwein Register, May 23, 1895, June 1, July 26, Aug. 31, 1898; Apr. 26, 1899; The Chicago Daily Tribune, Mar. 25, 1899; Stickney, A Short History, op. cit., pp. 5-6. 
tion of operating expenses had to be realized before any dividends would be forthcoming to C. G. W. stockholders! Earnings of the C. G. W. had dropped nearly twenty-nine per cent between 1893 and 1895. Stickney asserted that this decrease, which had continued through 1896 and 1897, was "not due to a lack of obtainable traffic, but solely to the inability of the line to carry it, due to the then poor physical condition of the property and the lack of equipment." Only new shops, situated at a more central location, such as Oelwein, could effect a lessening in operating expenses. The new locomotives were larger and heavier and could not adequately be cared for in the shops at St. Paul. And, the expense of hauling both locomotives and rolling stock all the way back to St. Paul for repairs was ever-increasing due to continual additions. By September, 1897, Stickney felt it was time to finish the shops. In his annual report to the C. G. W. stockholders in Chicago, September 9th, he stated: "The physical condition of the permanent way is better than ever before." Three months later, on December 6, at a meeting of the C. G. W. directors in St. Paul, he asked that Oppenheim be sent to England and apply to the C. G. W. finance committee in London for a loan of $\$ 1,100,000 ; \$ 250,000$ of which was to be used in finishing the Oelwein shops. The directors approved and early in January, 1898, Oppenheim obtained the money. The loan, at six per cent interest, was effected by Oppenheim signing debenture stock certificates which were held in London. ${ }^{34}$

And now let us return to Oelwein. After waiting nearly four years for the shops to be built, the businessmen had lost their enthusiasm. They were given the opportunity of buying C. G. W. debenture stock, with interest at four per cent, in October, 1897, but whether they did or not is not known at the present writing. It is doubtful that they

${ }^{34}$ Sitekney, A. B., Fifth Annual Report to the Stockholders, C. G. W. Ry. Co., Sept. 9, 1897, p. 30; The St. Paul Pioneer Press, Sept. 10, 1897; The Minneapolis Times, reprinted in The Oelwein Register, Sept. 29, 1897.

Stickney, A. B., Annual Letter to the C. G. W. Finance Committee, London, the Right Hon. William Lidderdale, chairman, Dec. 22, 1899, copied from C. G. W. Ry. Co., Corp. Ree., Vol. 2, p. 146.

Stickney, Fourth Annual Report to Board of Directors, op. cit.; Fifth Annual Report to Board of Directors, op. cit.; C. G. W. Ry. Co., Corp. Rec., Vol. 2, pp. 7, 97; The Oelwein Register, Oct. 19, 22, 1896. 
did, for most of them were very discouraged. They did not know of Stickney's plans. However, in February, 1898, the new Hotel Mealey was completed, and its owner, Michael Mealey, and manager, O. A. Cummings, learned that Stickney had a very important announcement concerning Oelwein. Consequently, the C. G. W. president was invited to be the main speaker at the formal opening of the hotel on the evening of February 21st. Stickney accepted, and, in response to the toast, "The C. G. W. Railway and Oelwein's Future,” by W. B. Ingersoll, mounted the stairsteps in the lobby and said $:^{35}$

We are going to build the machine shops this year. In 1898. There is no doubt about it. There are no ifs nor ands about it. The appropriation has been made, the contract has been let and the money is now ready and laid aside for this work. The shops will be commenced just as soon as the ground is in any condition for men to go to work.

Stickney was "cheered to the echo" by the business and professional men who had gathered to hear what he had to say. This was what they had been wanting to hear for years! No news could have been more welcome. All that they had hoped for in 1894 was now assured. Yet, "there were," to quote Woodruff, "some doubting Thomases who gravely shook their heads and said his words were as sounding brass or tinkling cymbal, and only spoken for effect.",

Stickney meant what he said about getting started, for in less than five weeks work was resumed on the foundations. During the first week of April additional tracks were laid to the shops' site. Men with teams and scoopshovels were put to work grading the grounds. Excavation for the foundations of the power house began the 18th. On the same day several car-loads of stone for the foundations arrived and were unloaded. The stone was from the Mantorville, Minnesota, quarries, and was brought in by the C. G. W. Following the C. G. W. direc-

${ }^{a 5}$ Burke, Mary Millard, Letter to author, July 24, 1942; The Oelwein Register, Oct. 13, 1897; Feb. 23, 1898; The St. Paul Pioneer Press, Oct. 21, 1897.

Ingersoll was an attorney. The Oelwein Record, Souvenir Edition, Dec. 10, 1897; Fitch, G. W., Past and Present of Fayette County, Iowa, 1910, pp. 1240-1242. soThe Oelwein Register, Feb. 23; Mar. 30, 1898. 
tors' decision to complete the shops, a branch line had been built in November, 1896, to Mantorville. On April 20, 1898 , work was resumed on the uncompleted foundations. During May building materials of all kinds and in everincreasing amounts arrived and were unloaded. Actual construction of the buildings above the foundations began June 11th, when bricklayers started work on the power house walls. ${ }^{37}$

\section{UnUsual Plan of Shops' ARRANGement}

Before discussing the erection of the shop buildings it would be well to know something of the general plan-the various shops, their purpose, and their location in relation to each other. The general layout had been planned sometime earlier by Lyon, assisted by C. A. Reed and Fay Berkley, architects of St. Paul, and H. A. Stahl, assistant engineer of the C. G. W. According to the conventional railway repair and machine shops of the 1890's, Lyon's arrangement was most unusual. As has been pointed out a rough sketch of the general layout appeared in the local press June 20, 1895. On February 23, 1898, the Oelwein Register carried a 3-column sketch of an architect's drawing of the proposed shops as they were to appear when completed. However, for a complete description of the buildings, including their specifications, reference to contemporary railway and engineering journals is best.

Two long buildings-one housing the general storehouse, the machine and erecting shop, the boiler shop, and the coach shop; the other consisting of the freightcar shop, the blacksmith shop, and the paint shop-facing each other, but separated by a transfer pit and table were to be built. Heading both buildings and the transfer pit and table was to be a long platform for loading and unloading. On the freight-car shop side of this platform was to be installed a large electric derrick. Just off the platform, at the derrick end, a wheel house, the power house, and scrap bins were to be built alongside the yard tracks. Beside the power house a brick smokestack 120 feet in

\footnotetext{
${ }^{27}$ The Oelwein Register, Nov. 26, 1896; Apr. 6, 20, 27, May 4, 11, June 15, 1898.
} 
height was to be erected. Immediately to the rear of the freight-car shop a lumber store, a wood mill, and a drykiln were to be constructed. On the far side of the paint shop was to be a small mixing room. Off the platform on the opposite side-the storehouse end-a water tank was to be placed on an eighty foot steel tower. Next, there was to be an oil house. To the rear of this building, and alongside the main building, was to be a lavatory and a clubhouse. Inside the main building, on a balcony to be built along the side furthest from the transfer pit, were to be the following rooms: an electricians' room, an air brake instruction room, an air brake repair room, an air hose work room, a lubricator and injector room, and a cleaning room - all above the machine shop; over the boiler shop were to be brass trimming rooms, a tin shop, a copper shop; and over the coach shop was to be a dye room, an upholstering room, a cabinet shop, an office, and a varnish room. A freight elevator was to connect the balcony with the floor of the main building. ${ }^{38}$

Ground space of the completed bulidings was to be as follows: Main building, three stories in height, $701 \mathrm{ft}$. $11 \frac{1}{2}$ in. by $93 \mathrm{ft} .10 \mathrm{in}$.; freight-car shop, $508 \mathrm{ft} .9 \mathrm{in}$. by a width varying from $50 \mathrm{ft}$. to $94 \mathrm{ft}$. The blacksmith and paint shops were to be $181 \mathrm{ft}$. by $60 \mathrm{ft}$. $1 \mathrm{in}$.; the mixing room, $35 \mathrm{ft} .11 \mathrm{in}$. by $35 \mathrm{ft} .11 \mathrm{in}$. The wheel shop was to be $42 \mathrm{ft} .10 \mathrm{in}$. by $32 \mathrm{ft}$. $10 \mathrm{in}$; ; the power house, $129 \mathrm{ft}$. $4 \mathrm{in}$. by $42 \mathrm{ft} .10 \mathrm{in}$; ; with a basement $46 \mathrm{ft} .4 \mathrm{in}$. by $13 \mathrm{ft}$. in size. The wood mill was to be $201 \mathrm{ft} .6 \mathrm{in}$. by $92 \mathrm{ft} .10$ in.; the lumber store, $94 \mathrm{ft}$. by $60 \mathrm{ft}$; ; and the dry-kiln, $29 \mathrm{ft}$. by $21 \mathrm{ft}$. The oil house, a two-storied structure, was to be $60 \mathrm{ft}$. by $32 \mathrm{ft}$. The lavatory and clubhouse, also a two-storied structure, was to be $100 \mathrm{ft} .10 \mathrm{in}$. by $53 \mathrm{ft}$. $10 \mathrm{in}$. The scrap bins were to be $97 \mathrm{ft}$. by $50 \mathrm{ft}$. in size. ${ }^{39}$

${ }^{38}$ C. G. W. Ry. Co., Corp. Rec., Vol. 1, p. 367 ; Damon, G. A., "Power Equipment for Railroad Shops," The Railroad Gazette, June 21, 1901, p. 430; American Engineering and Railroad Journal. July, 1900, p. 230, Aug., 1900, p. 251; The Railway Age, Apr. 24, 1903, p. 758.

The Oelwein Register, June 20,1895; Feb. 23, 1898; Mar. 22, Sept. 20, 1899 ; The Railway Age, Mar. 2, 1900, pp. 174, 181-189; Engineering News and American Railway Journal, Mar. 22, 1900, p. 185; Railway Master Mechanic, Mar., 1900, pp. 110-129; The Railway and Engineering Review. Apr. 16, 1898, pp. 200-201, Mar. 3, 1900, pp. 114-117, Mar. 10, 1900, pp. 128-130; June 25, 1904, pp. 459-464,

30The Oelwein Register, Mar. 22, Sept. 20, 1899; The Railway Age, Mar. 2, 


\section{Final Construction Work Resumed}

Construction of the buildings proper, as reported, began June 11, 1898. Hoff Bros., of Chicago and Minneapolis, had been awarded the contract for erecting the buildings. In his announcement at the opening of Hotel Mealey Stickney had stated that the contract had been let, but to whom he did not say. Not until March 30th was it known in Oelwein that Hoff Bros. were the contractors. Lowest of fifteen bidders, they had agreed, for the sum of $\$ 146,780$, to erect ten buildings, complete with water and sewer systems, by January 1, 1899. The Bion J. Arnold Electric Power Station Company of Chicago was contracted to install the power and lighting plant. B. F. Sturtevant \& Company, also of Chicago, was contracted for the heating system. This company engaged G. R. Morton, of St. Paul, to install the heat pipes. Early in June Reed and his assistant, T. Craig, came to Oelwein and supervised the erection of the buildings according to the architect's plans. ${ }^{40}$

Construction of the shops progressed "very satisfactorily" and by the end of June a high derrick had been completed for use in placing the girders in the main building. By July 15th five spans of girders were in place and brick-laying started at once. At the same time the power house and wood-mill girders were in place and two of the smaller buildings had been roofed. By the end of the month the brick smokestack at the power house had been built to a height of one hundred feet. Extreme hot weather the last week of June had delayed work on the water

1900, p. 185; Railway Master Mechanic, Mar., 1900, pp. 110-129; The Railway Master Mechanic, Mar., 1900, pp. 110-129; The Railway and Engineering. Review, Apr. 16,1898 , pp. 200-201, Mar. 3, 1900, pp. 114-117, Mar. 10, 1900, pp. 128-130 : June 25, 1904, pp. 459-464.

to The Oelwein Register, Feb, 23, Mar. 30, June 15, 1898; The St. Paul Pioneer Press, Mar. 23, 1898; The Chicago Daily Inter-Ocean, Apr. 18, 1898, reprinted in The Oelwein Register, Apr. 20, 1898; The Railway and Engineering Review, Apr. 16, 1898, pp. 200-201.

Damon, G. A." "Power Equipment for Railroad Shops," The Railroad Gazette, June 21, 1901, p. 430; Americen Engineering and Railroad Journal, July, 1900, p. 230, Aug., 1900, p. 251; The Railway Age, Apr. 24, 1903, p. 758.

The Oelwein Register, June 20, July 28, 1895; Mar. 22, June 21, 1899; The Railway and Engineering Review, Mar. 3, 1900, p. 114; The Railway Age, Mar. 2, 1900 , p. 181.

The Oelwein Register, Mar. 29, 1899; Railway and Engineering Review, Apr. 16,1898 , p. 201. 
and sewer systems, but by August 1 they were completed. On August 3rd it was reported that the steel framework of the main building was two-thirds up and the freightcar shop, the power house, and several of the smaller buildings were two-thirds completed. The smokestack was finished to its full height of 120 feet by the 11 th of August. ${ }^{41}$

As the shop building began to take shape it is interesting to note the attitude of Oelwein residents. Many persons were attracted to the shop grounds at the time the hoist, which was unusually high, was put up for placing the girders in the main building in position. On July 20 the Oelwein Register stated: "The shop grounds location is a busy scene and attracts many visitors daily." After seeing the completed smokestack on August 11, one individual exclaimed: "It looms up in great proportions and must be a land mark for many miles around." Newspaper men of neighboring towns, after reading accounts of the progress of the shops in the Oelwein Register sent to them by Woodruff, journeyed to Oelwein to see for themselves. Upon their return those from West Union, Waterloo, and Charles City wrote highly commendable articles. As a result, many out-of-town people came to visit the shop buildings. Following his visit, LeRoy Walker, of Clermont, wrote a poem which appeared in the Oelwein Register. In part, it is : ${ }^{42}$

\section{THE SECRET}

Why do people say so much to-day Of Oelwein in the State of Iowa?

Because her citizens now realize

Upon their months of works of enterprise ...

The Maple Leaf will keep her promise true;

The shops will soon be looming into view.

Surely all these things will make us grow!

Can't we a city have, I'd like to know?

Oelwein will boom in eighteen ninety-eight,

And make fine improvements here and there;

Become a leading city of the state

And will, I think, be talked of everywhere.

"1The Oelwein Register, June 15, 29, July 13, 20, 27, Aug. 4, 11, 1898.

42The Oelwein Register, Apr. 13, June 29, July 13, 20, 27, Aug. 11, 1898. 
Not long after another poem appeared in the local press. This one was written by Mary H. Millard, who then taught in a country school located three miles north of Oelwein. In her enthusiasm, upon visiting the shop buildings, she wrote "Rymes to Suit the Times," part of which is quoted here $:^{43}$

In the early morning,

Without a bit of warning,

A friend invited me to stray

Along the shop ground way.

And so I went like Minor P.

The strange new sights to see.

Arrived upon the noted spot,

Where a year ago shops were not.

We saw great walls uprising,

Which were indeed surprising.

Seven shops of large dimensions,

Claimed our close and strict attention.

Two hundred workmen, with much skill,

Were working there with sturdy will.

Brick and mortar, iron and sill,

Were placed like money in a till.

Compact and close to stand the wear,

Of vast machinery's awful tear.

And as we stood, we wondered much,

If in Oelwein were any such,

Who doubted now the good report

That a city here will be our forte...

\section{BUILDINGS TAKe FORM}

As construction of the shops continued through the autumn of 1898 Lyon predicted that the buildings would not only be completed, but that the machines would be in place and ready to run by January 1,1899 . According to the contract the buildings were to be finished by this date. Ten buildings were up, roofed, and enclosed by the first of the year, but they were not complete. Steam pipes were yet to be fitted; the water and sewer systems connected; power and light wires strung; and the lavatory and clubhouse building plastered. Nor were the machines in place and ready to run. Concrete foundations for the machines,

\footnotetext{
${ }^{43}$ Undated newspaper clipping sent to the author by Mary Millard Burke of Boone, Iowa, July 24, 1942.
} 
boilers, engines, and dynamos were yet to be poured. The C. G. W. directors had figured that two months' time, following the completion of the buildings on January 1st, would be needed for installing the machinery. In leasing the old shop buildings at St. Paul to Swift \& Company, a meat-packing concern, they had provided that possession not be given until March 1, 1899. Late in November, 1898, platforms had been built alongside special sidings for unloading the heavy machinery. During December the machines, all new - from the Niles Machine Company-arrived and were unloaded. Throughout January and February, as the foundations were poured, the equipment was put in place. Meanwhile, boilers, engines, dynamos, an air compressor, and an electric fire pump, were installed. A deep well, to furnish the water for the fire pump, was dug in the basmeent of the power house. H. B. Quick, of the Arnold Electric Power Station Company of Chicago, supervised installation of all electrical equipment. A. L. Ide \& Sons, of Springfield, Illinois, furnished and installed all engines and Mutual Electric Company of Chicago wired the shops. The steam fittings were completed by the second week of February, and during the following week the large electric traveling crane in the main building was installed. On the 18th it was tested. Built to lift and move a load of fifteen tons, at the rate of 500 feet per minute, the crane successfully lifted a load of $201 / 2$ tons ! ${ }^{44}$

Reference has been made to the "doubting Thomases" following Stickney's announcement that the shops were defínitely to be built in 1898. When freezing weather forced the workers inside in December rumors spread that again construction had stopped. In endeavoring to counteract these rumors, Woodruff, on two different occasions asserted that: "All they the persons convinced that construction had stopped have to do is to take a walk over to

\footnotetext{
4The Oelwein Register, Feb, 23, Mar. 30, Aug, 24, Oct. 12, Dec. 7, 1898, Jan. 18, Feb. 8, 22, Mar. 22, 1899; The St. Paul Pioneer Press, Mar, 23, 1898; The Chieago Daily Inter-Oeean, Apr. 18, 1898, reprinted in The Oelwein Register, Apr. 20, 1898; The Railway and Engineering Review, Apr. 16, 1898, pp. 200-201; Mar. 3, 1900, pp. 114, 116; The Railway Age, Mar. 2, 1900, pp. 181, 185; Engineering, News and American Railway Journal, Mar. 22, 1900, p. 185; The Railway Master Mechanic, Mar., 1900, p. 111; The Railroad Gazetie, June 21, 1901, p. 442, June 28 , 1901, pp. 461-462.
} 
the shop grounds and they will soon have that idea taken out of their minds." 45

It has been pointed out that the C. G. W. directors planned to evacuate the St. Paul shops by March 1, 1899 . But, when that date arrived, the Oelwein shops were not ready for occupancy and the St. Paul shops were operated for another three and a half months! At Oelwein, installation of machinery and equipment continued. Electric motors were bolted into position. An elevator was installed at the storehouse end of the main building. Offices for the general foreman and general storekeeper were constructed. The storehouse was completed. A 12inch brick wall was built separating the coach shop from the boiler shop. Fifteen tracks were built into the machine and erecting shop; five into the boiler shop; and six into the coach shop. Outside, between the two main buildings, the transfer table was completed and tested. The heating system for all shop buildings was completed. All buildings were heated by steam. The two largest buildings and the wood-mill were heated by forced hotair; all other buildings by direct radiation. It was estimated that nearly eight miles of piping went into the heating system. During March new tools arrived and were unpacked, catalogued, and arranged in the tool room. By the end of the month the engines and dynamos in the power house were in operation and "were doing their share toward the work of completing the shops." ${ }_{46}$

In his remarks at Hotel Mealey, February 21, 1898, Stickney had stated that the second story of the lavatory building was to be "a reading room." A year later, on March 17, 1899, in addressing the Fifth annual session of the Northeastern Iowa Press Association in Oelwein, he again referred to the lavatory and "clubhouse building."

In yonder cluster of buildings stands a building separate and part, which has no counterpart in the West. It is 50x100 feet and has no machinery. It will have in the lower story wash basins, sinks, lockers for men's clothing they do not wear while at work.

45The Oelwein Register, Mar. 30, 1898, Jan. 18, 1899.

46The Oelwein Register, Aug. 24, 1898, Mar. 22, 29, 1899.

47The Oelwein Register, Feb. 23, 1898, Mar. 22, 1899. 
The second story is a large assembly hall which may be divided later. This will be turned over to the employees of our shops for their comfort during their luncheon, and a place for rest and recreation while off duty. It will be christened Liberty Hall, typical of the employees of the C. G. W. road ...

The C. G. W. president was anxious to have a recreation hall finished by the time the shops were put into operation. He knew that, when the shop employees were transferred to Oelwein, many would have no place to spend their leisure time, except in their rooms- "which many times are cheerless places, where there is no companionship and little comforts." Contemporary shop employees recall that Stickney had personally paid for their "club rooms." For ten years, 1899-1909, the men enjoyed the privileges of Liberty Hall.48

With the work of installing machines and equipment progressing smoothly in the early part of April, 1899, completion of the lavatory and Liberty Hall was pushed. On the 5th it was reported that "a large gang of men are now at work on Liberty Hall, doing work on the interior." Woodruff went on to say: "When this building is finished it will indeed be a boon to many of the men ..." On the 26 th he reported "Liberty Hall is rapidly undergoing a transformation, and it will not be long before the workmen will be luxuriating in such things as nickel-plated soap dishes and the like. It will make a very nice place for the men to spend the hours while off duty." The club rooms were completed none too soon, for exactly four weeks later the shops were in operation $!^{49}$

\section{CoMPLETION OF SHOP BUILDINGS}

Oelwein shops were finally completed in April, 1899. During the second week of that month the floor was laid in the main building and the wheel shop was arranged for work. The latter building had been used as a blacksmith shop while the other buildings were being erected. On the 19th the dry-kiln was finished and a week later the floor of the balcony in the main was laid. The last few days

${ }^{48}$ The Oelwein Register, Apr. 5, 26, 1899; Shields, op. eit.

${ }^{49}$ The Oelwein Register, Apr. 26, May 24, 1899. 

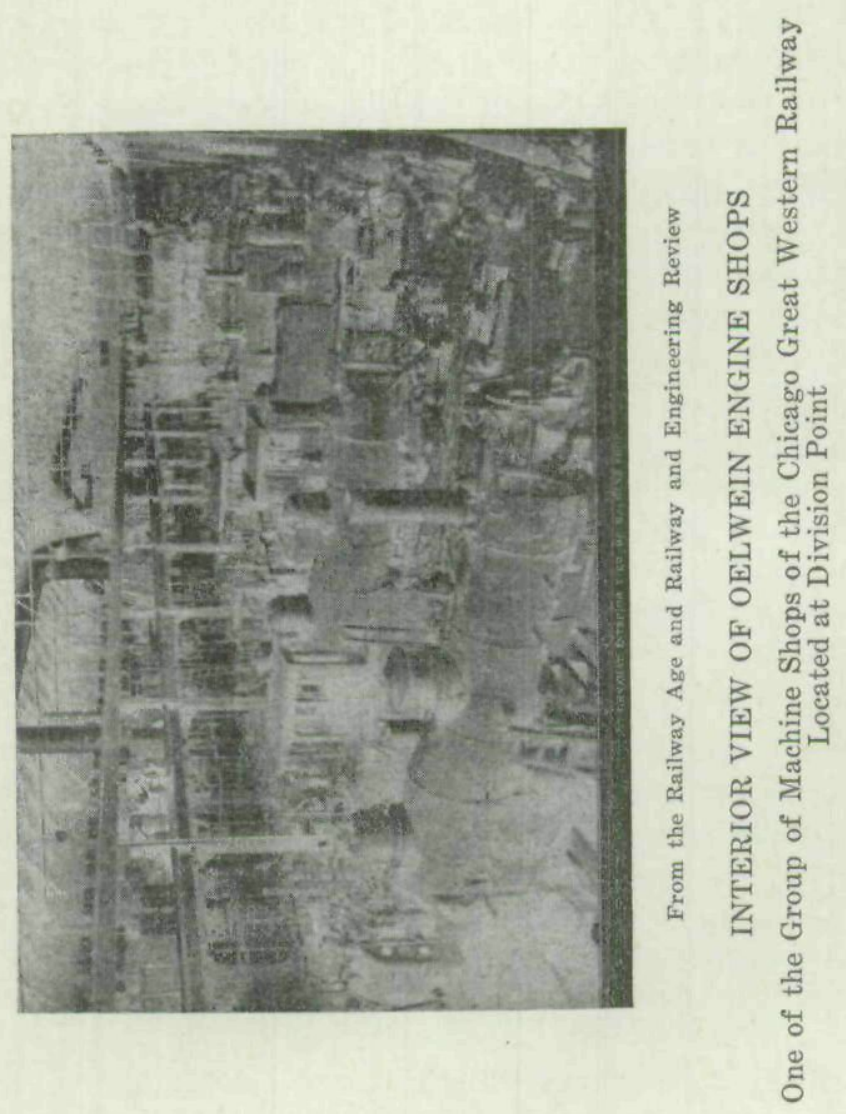
of April found machinists busy belting the machines and "getting ready for work!" The Oelwein Register announced that "the work of moving from St. Paul will begin inside of four weeks at the latest." 50

On May 24 the local press carried the headlines the businessmen of Oelwein had waited five years to see“THE SHOPS ARE RUNNING!" Føyr shops-the machine and erecting shop, the boiler shop, the freight-car shop, and the blacksmith shop-were then in operation with partial forces of men. Several carpenters had arrived two weeks earlier but instead of opening the wood mill, they were put to work doing carpentry work to finish up the various shops. The wood mill and the paint shop were opened the last week of May. On the 17th it had been reported that "inside three weeks there will be no more coach work done in St. Paul." Thus, three more shops were soon in operation. Woodruff noted the increased hustle about the shops. He said, "The busy hum of the machinery, together with the noise of the carpenters and masons, make the scene a busy one indeed." In talking with Joe M. Robb, general foreman of the shops, he learned that it was not practical to transfer all the men from St. Paul at the same time. Robb indicated that only as the men finished up their repair work in St. Paul would they be brought to Oelwein. Nevertheless, he did estimate that 150 men would be working regularly in Oelwein by the end of the month and by August 1st 400 men. Four days before the end of May Woodruff checked up on Robb. By counting the number of keys in use at the Bandy Time-clock at the main entrance he discovered that 154 men were working. ${ }^{51}$

The number of men to be employed in the shops was always a matter of interesting speculation. At the opening of Hotel Mealey Stickney had said, "We shall bring to your city and install in these shops 400 workmen." After being shown the buildings in September, 1898, a West Union editor declared: "This vast plant will require

${ }^{50}$ The Oelwein Register, Apr. 12, 19, 26, 1899.

${ }^{81}$ The Oelwein Register, May 17, 24, 31, 1899. 
not less than 260 men to operate..." Woodruff corrected this number by saying, "Here the shops are nearing completion and time rapidly approaching when from 500 to 1,000 men, most of them with families, will be moving here." When he saw the buildings the following month, Will Hartman, of the Waterloo Courier, predicted: "This improvement will add nearly 3,000 to the population of the city." Later, in December, Woodruff drew a comparison between the number employed by the Chicago, Milwaukee \& St. Paul Railway Company in its shops at Dubuque to those to be employed in Oelwein. To quote: "The Dubuque shops of the C. M. \& St. P. Railway give employment to 550 men ... just what the Great Western shops will do for Oelwein. Their shops here are built large enough to accommodate 1200 men-more than double the number employed in the C. M. \& St. P. shops at Dubuque." 52

Predictions continued. On February 6, 1899, Samuel G. Sloane, publisher of the Charles City Citizen, was in Oelwein and saw the shop buildings. Upon his return to Charles City he wrote: "The shops and works of the Railroad Company will give employment to at least 1500 men, which will mean the addition of not less than 3000 or 4000 to Oelwein's present population." In addressing the newspaper men of northeastern Iowa, March 17th, Stickney modified this estimate. Specifically, he said: "The entire number of workmen that can be employed is between 700 and 800 , but at present not that number will be employed. The entire machinery will be moved from St. Paul and the force of 350 men ... By fall 450 men will be regularly employed in the shops." On June 21st, after the shops were in operation, the Oelwein Register reported: "There are some 360 men employed in the Great Western shops and others arrive daily." A week later 400 workmen were said to be employed. On July 19th the press indicated: "The number of men now employed in the shops is nearer the 500 mark than 400." On Au-

52The Oelwein Register, Feb, 23, Sept. 21, 28, Dec. 21, 1898; The Waterloo Courier, Oct. 19, 1898, reprinted in The Oelwein Register, Oct. 26, 1898. 
gust 3rd Fred S. Robinson, who had succeeded Woodruff June 14, wrote: "It is reasonable to estimate that 1200 to 1500 men will be put to work in these shops after all being in full blast!"'53

\section{Employees Transferred From St. Paul}

With the transferring of the shop employees from St. Paul the housing problem in Oelwein became acute. At the time he had announced the shops were definitely to be built, Stickney referred to the necessity of providing houses for the shop men and their families. He said: "By next fall there must be a large number of residences erected in which the men can live... Some means or other will have to be provided for the erection of at least 300 dwellings in 1898 - at a total cost of $\$ 300,000$." Four years earlier, when the businessmen were endeavoring to raise money for building the shops, Stickney had told them that "About 500 dwelling houses should be ready for occupancy as soon as the shops are completed, to be increased to 1,000 dwelling houses within a very few years." As general manager of the Oelwein Land Company, House had planned to sell lots for homesites to the shop employees. But, when it was seen that the land company could not raise the building fund he had been replaced. On May 2, 1898, the C. G. W. directors announced that they planned to build one hundred brick houses in Jamison's addition during the coming summer. Jamison's addition became popularly known as "the reservation." The directors indicated that this was only the beginning, for "at least 200 other residences will have to be erected to provide living room for the shop men and their families alone, beside all the railway employees constantly being added to the population." ${ }^{\prime 4}$

The "C. G. W. houses" were started during the summer of 1898 as planned. In September an out-of-town editor was told that "There are to be built at once 300 or 400

${ }^{53}$ The Charles City Citizen, Feb. 6, 1899, reprinted in The Oelwein Register, Feb. 15, 1899; The Oelwein Register, Mar. 22, June 21, July 19, Aug. 3, 1899.

${ }^{54}$ The St. Paul Pioneer Press, June 3, 1894; The Oelwein Register. Apr. 7. op. cit.; Smith, Thomas, op. cit.; C. G. W. Ry. Co., Corp. Rec., Vol. 1, 1898; 421 . Belt, 
dwellings . . . and more next season as they are demanded." The fact that the railroad company was said to be building these houses resulted in the rumor that it was the intention of the C. G. W. directors to form a little "Pullman." Upon investigation it was learned that they had no such intention. Rather, they had sold lots to a Chicago contractor by the name of Murchie who was building at his own risk. When in Oelwein on October 19th Hartman noticed the new houses then being built. He was told that "A Chicago contractor is now building 110 cottages which will be rented or sold to the shop employees on the monthly installment plan.,"55

In investigating the rumor concerning the "C. G. W. houses," Woodruff became quite disturbed over the lack of building. Houses were already in demand-either to rent or to sell. In a note of alarm he wrote: ${ }^{56}$

There is more property changing hands, as shown by the county records, in Westgate, Arlington, and Maynard than in Oelwein ... We must wake up and be alive to the future of our city ... No town in Iowa has the prospects Oelwein has today.

Reference has been made to Stickney's remarks of March 17, 1899, before the newspaper men of northeastern Iowa. In discussing Oelwein's increasing population he said: ${ }^{57}$

By fall 450 men will be regularly employed in the shops besides the trainmen of the three divisions, thus in a general way adding to the population of 1899,450 workmen. At least two-thirds of these will be married men, and estimating four to a family, the population will be increased about 1,600 .

And, for the benefit of Oelwein businessmen, the C. G. W. president declared: ${ }^{58}$

The effect of this added population to trade, in general, goes without saying. It is an important guess as to what effect the introduction of 450 to 500 voters in a population of 800 voters will have of men engaged in one employment. It is important to know how this will affect the community socially, politically, and otherwise. I think I can assure you it will not affect the sobriety of

${ }^{5}$ The Oelwein Register, Sept. 21, 1898; The Waterloo Courier, Oct. 19, 1898, reprinted in The Oelwein Register, Oct. 26, 1898.

5eThe Oelwein Register, Sept. 28, 1898.

s7The Oelwein Register, Mar. 22, 1899.

58The Oelwein Register, Mar, 22, 1899. 
Oelwein unfavorably ... The tone of C. G. W. employees has been decidedly elevated in the past few years...

Of the relations between the railroad and its employees, the C. G. W. is not an imperial power. It has nothing to do with politics, local, state or national. It does not purchase, nor will it control, its employees' conscience, religion, or politics.

Now, gentlemen, the shops are here. It will not be long until others will be here ... Gentlemen, the future of Oelwein is in the hands of the people. The people have got to make the city. Let Oelwein pursue individual enterprise. The railroad will not interfere, assist or manage the economic program. You have the opportunity - the shops give the opportunity-gather in all the trade you can from surrounding country and villages. Now then, go for the towns along the Burlington road-do not bother with Westgate, and you will have a prosperous town!

\section{Housing Problems Continued}

Woodruff's alarm at the shortage of houses in September, 1898, was emphasized in June and July of 1899, at the time the shop workers were being transferred from St. Paul. There just were not enough houses to go around. The houses being built by Murchie were not ready for occupancy until the middle of July. In fact, it was several weeks more before many of them could be occupied.59

At the time the shops were opening Robb expressed his previous anxiety concerning the housing situation in Oelwein. He stated that it had long been known among the shop men at St. Paul that houses were scarce in Oelwein. Many men resigned their jobs rather than be unable to take their families to Oelwein. In talking with those men who had secured houses, Robinson learned that, generally speaking, they had brought their families and belongings to Oelwein and that they liked their new surroundings very well. But, those who had not found places to live were living apart from their families and were generally dissatisfied. Many of the latter were unable to pay their own expenses in Oelwein and also maintain their families in St. Paul or Minneapolis, so planned to give up their jobs and return to the Twin Cities. Robinson realized the situation was desperate and in his next issue wrote: ${ }^{60}$

59The Oelwein Register, Sept. 28, 1898, June 14, July 12, 1899.

${ }^{6}$ The Oelwein Register, May 28, Sept. 20, 1899. 
The fact of the matter is that more houses must be provided and soon, or our city, as well as the railroad people, will lose men who are valuable as citizens and employees. Money can no more profitably or securely be invested than in houses in Oelwein, and capitalists will find it to their advantage to turn their attention to this line of business.

The personal recollections of three contemporary shop men concerning the housing situation in Oelwein are appropriate at this time. Ralph Ramwell, foreman of the machine shop, recalls that he, a single man with no family, had difficulty in finding a place to board and room. Before leaving St. Paul he sent ahead one of his gang bosses especially to locate a place where he might live. In this way he succeeded in obtaining board and room together. Not long after his arrival in Oelwein, however, he changed boarding places. He went to board at the same place as did Sidney T. Corris, foreman of the coach shop. M. J. "Mike" Rogge, a "lead man" in the machine shop, arranged for his wife and two children to come to Oelwein a month after his arrival. However, for over a year they had to rent furnished rooms and board in the home of a private family! Mike recalls that he simply could not find a house. J. Kirk Shields, formerly of Montreal, was employed by the C. G. W. May 30th to work in the erecting shop. When asked if he had had difficulty in finding a place to live Shields replied: "I had to take half a day off just to find a place to board and room. I walked the streets half an afternoon, but did find a good place to eat. The food was good and not too expensive." 61

\section{VISITORS SWARM NEW BUILDINGS}

Mention has been made of the visitors to the shop buildings. During the winter of 1898-1899, after the buildings had been erected and the workers moved inside, Woodruff began to encourage more people to visit the buildings. Even earlier, out-of-town editors recommended a trip to Oelwein to see the structures. To quote one, in particular: ${ }^{62}$

\footnotetext{
${ }^{61}$ Ramwell, Ralph, statement to author, July 27, 1942 ; Rogge, M. J., statement to author, June 3, 1942; Shields, op. cit.

"The Oelwein Register, Sept. 21, 1898, Jan. 18, 1899.
} 
Never were we able to appreciate till now the immensity of the structures ... Now that the walls are up and the roof on one can comprehend the greatness of an edifice that is 710 feet in length... There are six or eight more great buildings in process of erection.

After he had seen the buildings January 27, 1899, another northeastern Iowa newspaper publisher asserted: "No one can describe these mammoth buildings and they must be seen to be appreciated." 63

Sightseers came in ever-increasing numbers. On Sunday afternoon, February 18, "the C. G. W. shop grounds and buildings were fairly alive with people." After securing Stickney as the main speaker for the Fifth annual session of the Northeastern Iowa Press Association, March 17, and a tour of the shops afterward, Woodruff fairly outdid himself in describing the shops. After this visitors flocked to see the shops. ${ }^{64}$

With the new machines and equipment being placed in position, it became necessary for the C. G. W. to adopt protective measures. Beginning in February, the shop grounds were "closed to visitors" on Sundays. Passes were issued on week days only. Sightseers, however, were permitted on the grounds and in the buildings only with an escort. During March no admittance and keep out signs were put up and by the time the shops were put into operation on May 24 an eight-foot fence, made of boards topped with strands of barbed wire, enclosed the buildings. The fence was an unexpected expense, but the railway officials figured it was cheaper than maintaining a large force of watchmen night and day. Instead of obtaining passes and looking at the buildings under escort, many people had attempted to go wherever they pleased. Consequently, the fence had been put up. ${ }^{65}$

During June the shops presented a busy appearance. Some of the machines that had been brought from the St. Paul shops were placed in position. Repair work mounted rapidly. On the fourteenth twelve engines and

\footnotetext{
"अThe Oelwein Register, Feb. 1, 1899.

${ }^{{ }^{6} T}$ The Oelwein Register, Feb. 22, Mar. 22, 1899.

osThe Oelwein Register, Feb. 22, Mar. 22, 29, May 24, 1899; The Railway and Engineering Review, Mar. 10, 1900, p. 128.
} 
as many coaches and freight-cars were being repaired. The engine and coaches, with the exception of a Pullman sleeper, wrecked north of Oelwein on the night of May 28 , were undergoing repairs. By the middle of July nearly five hundred men were at work in the shops; yet the repair work continued to pile up! The machine shop foreman recalls: "The work got heavier all the time." A night shift was started. In visiting the freight-car shop Saturday afternoon, July 15, Robinson noted that sixteen cars were under repair. He declared: "As soon as one of them is completed, there are others on the track to take its place... The work continues days and evenings, and then the repair work accumulates. It looks as though still more men would be required." 66

When they saw that the shops were in operation Oelwein businessmen decided to arrange some sort of welcome for the workmen. Although they preferred to wait until the shops were running in full capacity before undertaking a celebration, the merchants felt they should do something "informal" for the "new" citizens. On July 11 Mayor Ben E. Hough and O. A. Cummings, the latter manager of Hotel Mealey, solicited and "easily raised" the necessary funds. That evening, at a meeting in the "parlours" of Hotel Mealey, the businessmen decided to give a reception in Hotel Mealey the following Monday evening, July 17th. They publicly extended an invitation to all "new" citizens of Oelwein to attend. ${ }^{67}$

And attend they did! Although preparations were not completed in time for the reception to be held as planned, it was given the following evening, Tuesday, July 18th, from 8:30-11:00 P. M. Over a thousand people thronged through the street floor of the hotel. Attractive programs, printed by the Oelwein Register staff, were handed the arrivals at the doors. The program was arranged by Cummings, ex-mayor W. M. Peek, John Jamison, and J. R. Hall. At 9:30 P. M. Peek introduced Mayor Hough

\footnotetext{
"0The Oelwein Register, May 31, June 14, 21, July 19, 1899; The Chicago Daily Tribune, May 29, 1899; The Chicago Evening Journal, May 29, 1899; Ramwell, op. cit.

ตтThe Oelwein Register, May 10, July 12, 19, 1899.
} 
who made a few remarks of welcome. In response, Robb spoke on behalf of the shop employees. Following numbers by a male quartet a telegram from Stickney was read. In it he expressed his regret at not being able to be present and give the main address. "Business matters" prevented his attending. Next, an orchestra rendered several selections. T. J. Gilbert, foreman of the woodmill, then gave a "witty address that called forth laughter and applause." He was "dramatic, humorous, and entertaining." He was followed by men representing the "old" and the "new" citizens. Speakers for the older citizens included John Jamison, Smith Hough, A. J. Anders, George H. Phillips, W. B. Ingersoll, and Dr. J. F. Cole. The "new" citizens were represented, in addition to Gilbert, by J. Carruthers, T. W. Ferguson, and Sidney T. Corris. Following their remarks a "mixer" was held during which time refreshments were served and music furnished by the orchestra. As reported, the mixer was as follows : 68

Everyone was treated to fruits and Roman Punch, and an abundance of fine cigars of the ten cent straight variety, were passed around to the male portion of the crowd. A number of young ladies had charge of the drinking booth where the punch was dispensed to the thirsty. The boys enjoyed the cigars and the smoke of their incense ascended to the upper apartments.

Robinson was on hand and declared the reception was a great success. He was convinced that: "No city in Hawkeyedom presents more intelligent, cultured, and upto-date citizens than the Shop City of Northeastern Iowa!"69

es Souvenir Program, Oelwein Businessmen's Reception for the "New Citizens," July 18, 1899; The Oelwein Register, July 19, 1899. Souvenir Program given to July 18, 1899: The Millard Burke, July 24, 1942. Fred S. Robinson, publisher of The Oelwein Register, also preserved one of these programs.

Peek was a former hotel manager; but was then a dealer in farm implements. Fitch, op. cit., Vol. 1, pp. 802-804.

Hough was a retired farmer. Phillips, Ray B., statement to author, Aug. 1, 1942.

Anders was an attorney. The Oelwein Record, Souvenir Edition, op. eit.

Phillips was an attorney for the C. G. W. Phillips, Ray B., op. cit.; Deyo, E. E. superintendent, Illinois Division, C. G. W. Ry., letter to B. F. Parsons, assistant to the president, Oet. 29, 1941; Fitch, op. cit., Vol, 1, pp. 636-637.

Ingersoll was an attorney. Fitch, op. cit., Vol. 2, pp. 1240-1242.

Cole was a physician and surgeon. Fitch, op. cit., Vol. 1, pp. 618-622.

Corris was foreman of the coach shop. The Oelwein Register, July 19, Sept.

28, 1899: Poor's Manual of the Railroads of the United States for 1900, p. 1438.

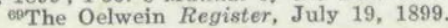




\section{Celebration Early Planned}

First indications of a celebration in honor of the coming of the shops appeared in October, 1898, as the buildings were being enclosed. After seeing the structures Hartman, of the Waterloo Courier, wrote: $:^{70}$

Oelwein will, of course, have a great celebration when the shops are completed and arrangements are now being made for a midwinter fair. The shops will be given over to the city in the days of the fair for the displays. No arrangements have been completed, but the fair will be something unique and interesting.

No mid-winter fair was held, however, and it was not until April 22, 1899, that Oelwein businessmen met to discuss the idea of having a celebration. That evening, in the City Hall, they listened to Mr. Hurd, of Hurd, Shaw \& Odell, realtors, state that Stickney had recently informed him that if a celebration was to be held he thought the best time would be around May 15-20. By then, Stickney indicated, the shops would be nearly, if not completely, equipped, and "visitors would be better able to see the shops than if the men were at work. Besides, it will be several months before the shops are running in full blast."71

In the discussion that followed two viewpoints developed. Some of the merchants felt that Stickney's suggestion should be followed. Others, however, were of the opinion that no celebration should be attempted until the shops were in full operation. Although no decision was made at this meeting, Mayor Hough appointed a committee on arrangements consisting of George Phillips, John H. Millard, John Jamison, William Bentley, and W. H. Meyer. In reporting the meeting Woodruff wrote $:^{72}$

ENTHUSIASTIC CITIZENS WILL ARRANGE FOR A BIG BLOW-OUT IN HONOR OF C. G. W. SHOPS

We can think of no better way of showing our appreciation for what the C. G. W. road has done for our city than by inviting all who will to be present on this occasion and see the finest shop buildings west of the Mississippi River ...

\footnotetext{
70The Waterloo Courier, Oct. 19, 1898, reprinted in The Oelwein Register, Oct. 26. 1898 .

71The Oelwein Register, Apr. 26, 1899.

72The Oelwein Register, Apr. 26, 1899.
} 
President Stickney has already consented to deliver an address, and Governor Shaw will be invited to speak ... Every effort will be made to make this the grandest celebration in the annals of history of Oelwein and Fayette county.

On May 5th, after two weeks of investigation, members of the committee on arrangements voted to postpone the celebration indefinitely! The press reported that: "This action was taken in deference to Mr. Stickney, who advised the committee on arrangements to wait."73

Wait the committee did! Four months! Not until the sixth day of September did the businessmen instruct the committee to go ahead in making definite arrangements for the celebration. The committee agreed that the main speakers should be President Stickney and Governor Shaw. Brief remarks, however, were to be made by Congressman L. L. Ainsworth, Judge William A. Hoyt, and S. B. Zeigler, pioneer banker of Fayette county. Following the speaking the committee planned that a "grand field meet" be held. In the evening a band concert was to be given on the street which was to be followed by a "ball."74

While the committee went ahead with its plans for the celebration Robinson wrote long, descriptive articles in the Oelwein Register about "the best and finest equipped shops owned by any railroad west of Chicago." In one article he wrote $:^{75}$

A writeup of the business interests of Oelwein without mention of the great shops of the C. G. W. Railway would be like pointing to the play of Hamlet with Hamlet left out! This great industrial plant .... is the chief source of the city's prosperity.

Once they had agreed that the celebration occur, Oelwein businessmen were anxious to hold it as soon as possible. The committee on arrangements experienced, however, several delays. First, Stickney declined to deliver the address he had previously promised to give. Daniel W. Lawler, general solicitor of the C. G. W., was recom-

73The Oelwein Register, May 10, 1899.

${ }^{74}$ The Olewein Register, Sept. 13, 20, 1899.

75The Oelwein Register, Sept. 20, 27, 1899. 
mended and secured in his place. Next, Governor Shaw delayed his reply. Lacking Stickney, the committee members were all the more anxious that the governor be secured to speak at the celebration. Subsequently, they withheld announcing the exact date for the celebration until he did reply. Not until the 27th of the month did the local newspapers announce the date of the celebration-Thursday, September 28th-the date most suitable to Governor Shaw. The Oelwein Register emblazoned the following writeup on its front page $:^{76}$

\section{RAILROAD SHOPS OPENING TOMORROW WITH FITTING CEREMONIES}

"It is especially appropriate that a day be set apart to celebrate the location and opening of the shops here. Tomorrow will be devoted to a grand formal opening, and addresses will be delivered by prominent citizens of the State and officials of the C. G. W. . .

During the day the shops will be opened for inspection and everyone will have an opportunity of looking through one of the most extensive railway plants in the world...

\section{Decorations and Ceremonies of Day}

The day of the celebration was windy and chilly. The sky was cloudy and rain fell throughout the day. The businessmen, particularly those along Charles street, Jefferson and Frederick avenues, decorated their places of business for the occasion. Many residences were decorated. At the intersection of Charles and Jefferson two arches of electric lights were erected. Excursions were run by the C. G. W. from all points along the line. Thousands of people were in Oelwein for the celebration; yet many had not learned of the exact date. And, the bad weather undoubtedly kept others away. ${ }^{77}$

During the morning and early afternoon all shops held an "open house" in which the workmen acted as guides for the visitors. The coach shop, with ample open space for the speaker's platform and chairs for an audience, was arranged for the speaking. At 3:00 P. M. ex-mayor Peek, who had been asked to preside, introduced the Rev.

${ }^{76}$ The Oelwein Register, Sept. 27, 1899.

${ }^{{ }^{7} T h e}$ Oelwein Register, Oct. 4, 1899 ; Shields, op. cit.; Oelberg, op. cit. 
S. Conybeare, of the Oelwein Presbyterian church, who gave the invocation. As the first speaker, Daniel W. Lawler delivered "an eloquent address that was well received." He prophesied a great future for Oelwein. In his speech Col. Lyon, of Dubuque, reviewed the history of the C. G. W. and its predecessor companies. He was followed by Governor Leslie M. Shaw, whose address "brought forth frequent cheers." The speaking was concluded with brief remarks by the Hon. L. L. Ainsworth, Judge W. A. Hoyt, and S. B. Zeigler, all prominent citizens of Fayette County. In the intermissions between the speeches the Shop City band rendered "some catchy selections in a high class manner that brought forth frequent applause."78

At the conclusion of the speaking running contests between the Oelwein and Sumner fire departments were held. The "grand field meet" never took place. However, the band concert did occur in the evening as planned. Under the two electric archways at the intersection of Charles street and Jefferson avenue the Shop City band played to an enthusiastic crowd. Following the concert a "firemen's ball" was given in Liberty Hall, the new clubhouse. This event "entertained the guests and city people till a late hour." 79

And so we have seen how the main machine and repair shops of the C. G. W. Railway Company were financed and constructed in Oelwein between 1894 and 1899. During the early months of 1899 , after the buildings had been enclosed, the machines and equipment were installed; the shops being put in operation by the 24th of May. Formal opening of the shops occurred four months later; the workmen being given an informal reception in July. Detailed description of the shops-the location of various machines, tools, equipment; the power, lighting, heating, water and sewer systems; and fire prevention measuresare other stories.

\footnotetext{
78The Oelwein Register, Oct. 4, 1899: Fitch, op. cit., Vol. 1, pp. 563-566, Vol. 2, p. Iowa 1878 , 595; Shambaugh, B. F., Progressive Men of Iowa, pp. 122-124.

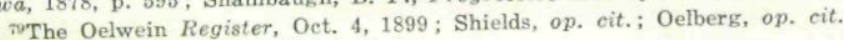


A description of the work done in the shops-both repair and construction-would make still another story. And, the effects - political and social-of the coming of the shop employees to Oelwein would make an appropriate history. But for the economic effects, with which the Oelwein businessmen had been concerned primarily, let us return to Winder's Opera House, Saturday evening, June 2, 1894, where Stickney had declared: "As an element of permanent prosperity to a village or city, railway shops are superior ... inasmuch as they continue to run as long as the railway runs, which is forever ..." The business and professional men of '94 foresaw that their own interests would be furthered if they secured the C. G. W. shops for Oelwein. Their successors have since been vitally interested in the continued operation of the shops. Today, Oelwein businessmen depend upon the shops for their prosperity. Stickney concluded his remarks fifty years ago by picturing Oelwein as "a compactly built city with comfortable homes and beautiful parks; with a garden in the rear, a nicely-kept lawn in front extending to well-paved streets lined with shade trees, and inhabited by 10,000 happy men and women." And, isn't that just what Oelwein is today ? $^{80}$

\section{IOWA CAPITAL REMOVAL}

The Iowa Statesman asks us if the law in relation to the relocation of the capital of the state is constitutional! We have not declared it to be otherwise; we merely stated as a matter of news that we understand the commissioners appointed by the Governor to locate the capital, would be enjoined, as we understood they would be, from proceeding to discharge the duties imposed upon them. We are far from throwing any obstacles in the way of having a relocation of capital made as is contemplated by law, and as was intended by a decided majority of the General Assembly. We are with you on the capital question Mr. Statesman.-Dubuque Express and Herald, May 2, 1855.

\footnotetext{
50The St. Paul Pioneer Press, June 3, 1894; The Oelwein Register, June 7, 1894 ; Belt, op. cit.; Oelberg, op. eit.; Smith, Thomas, op. eit.

The United States Census of 1900 gave Oelwein a population of 5,152 . In 1940 Oelwein had 7,801 inhabitants. The Oelwein Register, Sept. 26, Nov. 1, 1900;
} 
Copyright of Annals of Iowa is the property of State of Iowa, by \& through the State Historical Society of Iowa and its content may not be copied or emailed to multiple sites or posted to a listserv without the copyright holder's express written permission. However, users may print, download, or email articles for individual use. 